Am Hahnenblutdruck bewirkte das Nonapeptid - bis zu $0,4 \mathrm{ml}$ der unverdünnten Lösung - im Gegensatz zu HHL und zu Oxytocin keine Blutdrucksenkung. Wurden 15 bis $30 \mathrm{sec}$ nach Verabreichung von 0,3 und $0,4 \mathrm{ml}$ unverdünnter Nonapeptidlösung 75 Millieinheiten HHL injiziert, so blieb der sonst regelmäßig durch HHL ausgelöste Blutdruckabfall aus (Fig. 1). In gleicher Weise wurde durch das Nonapeptid die depressorische Wirkung von Oxytocin verhindert. Bei Ausdehnung des zeitlichen Intervalls zwischen der Injektion des Nonapeptids und des $H H L$ bzw. von Oxytocin nahm die Hemmung der Blutdrucksenkung ab (Fig. 1). Bei einem Intervall von 2 min war kein Hemmeffekt mehr zu beobachten.

Am isolierten Rattenuterus bewirkte das Nonapeptid keine Kontraktion der Muskulatur, vermochte aber die durch 8 bis 20 Millieinheiten Oxytocin bedingte Kontraktion zu vermindern bzw. $z u$ verhindern, wenn $30 \mathrm{sec}$ vorher 0,04 bis $0,16 \mathrm{ml}$ der unverdünnten Lösung dem Organbad $(50 \mathrm{ml}) \mathrm{zu}$ gesetzt worden waren (Fig. 2).

Das Homologe des Oxytocins verhielt sich also in den beiden genannten Testen qualitativ gleich, indem es die Wirkung nachfolgenden Oxytocins abzuschwächen oder völllig
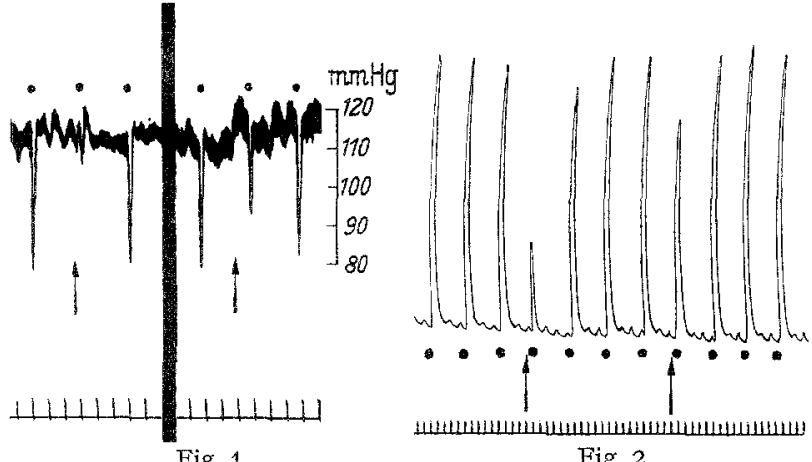

Fig. 2

Fig. 1, Hemmung der Wirkung von HHL am Hahnen-Blutdruck durch Vorbehandlung mit dem Nonapeptid. Alle 3 min wurden 75 Millieinheiten HHL injiziert (weißer Punkt); $0,3 \mathrm{ml}$ unverdünnte Nonapeptidlösung wurde bei $\uparrow$ (links) $15 \mathrm{sec}$ und bei $\uparrow$ (rechts) $1 \mathrm{~min}$ vor HHL injiziert

Fig. 2. Hemmung der Oxytoxinwirkung durch das Nonapeptid am isolierten Rattenuterus. Alle 5 min (weißer Punkt) wurden 8 Millieinheiten Oxytocin dem Organbad $(50 \mathrm{ml})$ zugesetzt und nach erfolgter Uterus-Kontraktion wieder ausgewaschen. Bei $\uparrow$ (inks) wurden $0,1 \mathrm{ml}$, bei $\uparrow$ (rechts) $0,064 \mathrm{ml}$ unverdünnte Nonapeptidlösung, jeweils $30 \mathrm{sec}$ vor der nächsten Oxytocindosis, zugegeben

zu hemmen vermochte. Eine quantitative Schätzung ergibt, daß in beiden Testen 300 bis 600 mal mehr Gewichtseinheiten vom. Nonapeptid als von Oxytocin notwendig sind, um die Wirkung von Oxytocin zu 75 bis $100 \%$ zu hemmen.

Der Druck im Milchdrüsenausführungsgang laktierende Kaninchen wurde durch das Nonapeptid erhöht, wenn 0,016 ml und mehr der unverdünnten Lösung pro Tier injiziert wurde. Im Vergleich zu Oxytocin war das Nonapeptid hier etwa $500 \mathrm{mal}$ schwächer wirksam. Einen sicheren. Hemmeffekt gegenüber Oxytocin zeigte das Nonapeptid in diesen Versuchen nicht.

Aus den mitgeteilten Befunden geht hervor, daß die Oxytocinwirkung an einzelnen Testobjekten durch ein homologes Polypeptid gehemmt werden kann, dem in einem anderen Test noch ein Rest oxytocischer Wirksamkeit zukommt. Weitere Untersuchungen zur Aufklärung des Wirkungsmechanismus in vitro und in vivo sind im Gange.

Pharmazeutisch-Chemisches Laboratorium der Sandoz A.G., Basel

St. Guttmann, P.-A. Jaquenoud und R.A. Boissonnas

Pharmakologisches Laboratorium der Sandoz A.G., Basel H. KONZETT und B. BERDE

Eingegangen am 12. Oktober 1957

1) Botssonnas, R. A., St. Gutrmann, P.-A. Jaquenoud, J.-P. WALLER, H. KONZETT u. B. BERDE: Nature [London] 178, 260 (1956). - 2) Boissonnas, R.A., St. Guttmann, P.-A. Jaguenovd u. J.-P. WALler: Helv. chim. Acta 39, 1421 (1956). - 3) BERDE, B., W. Doepraner u. H. Konzett: Brit. J. Pharmacol, 12, 209 (1957). 4) Borssonnas, R.A., St. Guttmans, P.-A. Jaquenoud u. J.-P. WALler: Helv, chim. Acta 38, 1491 (1955). - 5) VIGNEAUd, V. DU Ch. Ressler, J. M. SWan, C. W. Roberts u. P. G. Katsoyannis: J. Amer. Chem. Soc. 76, 3115 (1954).

Naturwiss. 1957

\section{On the Reactivity of Pyridine-N-Oxide}

Pyridine-N-oxide occupies an unique position in the quantum mechanical theory of organic reactivity. It undergoes both cationoid and anionoid substitution at the same positions, namely primarily at 4 and to a lesser extent at 2 position. The molecular orbital method of calculating electron density cannot correctly predict the reactivity of this compound, since it cannot predict maximum electrophilic and nucleophilic reactivity for the same position. Accordingly pyridine- $\mathrm{N}$-oxide is an example of a compound violating the non-crossing rule. This peculiarity of $N$-oxide has been explained by the contribution of the various chargeseparated canonical structures to the resonance hybrid in the valence bond approximation and by the fact that the $\mathrm{N}$-oxide function is strongly polarizable in both directions.
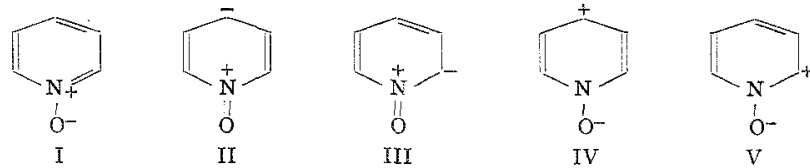

Object of the present investigation is to show that molecular orbital can explain this peculiar reactivity of $N$-oxide. First we make a straightforward $\mathrm{MO}$ calculation of the electron densities at various positions of the pyridine-N-oxide. We have used the following values for the MO parameters of the hetero atoms,

$$
\text { Coulomb integral } \quad E_{\mathrm{O}}=E_{\mathrm{C}}+2 \beta \quad \text { and }
$$

$$
\left.E_{\mathrm{N}}=E_{\mathrm{C}}+\beta, \quad E_{\mathrm{C}^{\prime}}=E_{\mathrm{C}}+0 \cdot 0-1 \beta \quad \text { (C attached to } \mathrm{N}\right)
$$

Resonance integral $\beta_{\mathrm{C}-\mathrm{N}}=0.6 \beta_{\mathrm{C}-\mathrm{C}}$ and $\beta_{\mathrm{N}-\mathrm{C}}=1.2 \beta_{\mathrm{C}-\mathrm{C}}$.

The calculated electron densities are shown in the Fig. 1. It is evident that anionoid attack should be at 4 and 2 positions, as is actually the case. The cationoid attack should, however, take place at 3 position, while in actual practice the positions attacked are 4 and 2 . Now the cationoid attack means nitration, sulphonation, etc., which are usually performed in strongly acidic medium. It is logical to expect that in acidic medium the compound exists primarily as IV and $V$, and there will be a strong tendency for protonation of oxygen. In the structure of the type IV and V with negatively charged oxygen, the electron affinity, hence the coulomb integral of oxygen will be reduced, compared to neutral (or almost neutral) oxygen as used in the first calculation. We may set this approximately equal to $E_{\mathrm{C}}+\beta$ instead of $E_{\mathrm{C}}+2 \beta$ used previously. The recalculated electron densities are shown in the Fig. 2. It is evident that the cationoid attack should

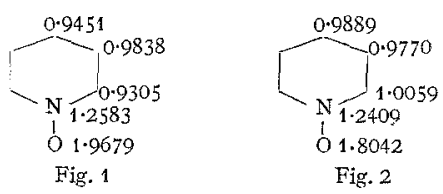

Fig. 1 and 2. Calculated resp. recalculated electron densities. (See text)

now go to 2 and 4 positions, as is observed experimentally. In practice the 4 position is more reactive than the 2 position probably because of steric requirements and the proximity of a positively charged nitrogen atom at 1 position. Similar conclusion was arrived at by JAFFE ${ }^{1}$ ) from the localisation energies of the various positions in pyridine-N-oxide.

Apart from the importance for its own shake the present analysis shows that the reactivity of an organic compound is determined not by the structure, as it is written on paper. alone, but also by the nature of the medium into which the compound finds itself.

Department of Chemistry, University College of Science, 92 Upper Circular Road, Calcutta-9, India

SaDHAN BasU and KaNAI LAI SaHA

Eingegangen am 31. Oktober 1957

1) JAFFE: J. Amer. Chem. Soc. 76, 3527 (1954).

Digoxigenin-mono- und -bis-digitoxosid, zwei neue Glykoside der Digitalis lanata*)

In unserer 8. Mitteilung ${ }^{1}$ ) über Herzglykoside haben wir die Isolierung der Mono- und Bis-digitoxoside von Digitoxigenin, Gitoxigenin und Gitaloxigenin aus den Blättern von Digitalis purpurea beschrieben und erwähnt, daß Glykoside 